\title{
OOROIASIOHO
}

\section{PERLAKUAN ABU BIJI KAPUK RANDU UNTUK BAHAN KAMPAS REM KENDARAAN BERMOTOR}

\author{
*Gunawan Dwi Haryadi ${ }^{a}$, Chrisman ${ }^{a}$, Agus Tri Hardjuno ${ }^{b}$ \\ a Jurusan Teknik Mesin, Fakultas Teknik, Universitas Diponegoro \\ ${ }^{\mathrm{b}}$ UTP Terpadu, Universitas Diponegoro \\ Jl. Prof. Sudharto, SH., Tembalang-Semarang 50275 \\ *E-mail: gunawan_dh@yahoo.com
}

\begin{abstract}
ABSTRAK
Aplikasi serat alam dan serat mineral terutama non logam sebagai bahan kampas rem secara bertahap dilakukan dengan seleksi bahan serat (jenis), perlakuan (kimia dan fisik) awal bahan, uji kualitas bahan murni, seleksi pengikat (binder), penentuan susunan serat, pembentukan bahan komposit, perlakuan panas (heat treatment) dan uji kualitas bahan komposit. Serat alam (yang telah diurai) diberi perlakuan secara kimia meliputi perlakuan permukaan. Serat alam diberi perlakuan fisik melalui pemanasan pada kondisi terukur, penempaan dan pendinginan dengan kondisi terukur. Mekanisme pembentukan bahan kampas rem dengan bahan serat alam, serat mineral non logam dan pengikat meliputi butirisasi bahan, penentuan komposisi, pencampuran, pemadatan, perlakuan panas (sintering) dan uji kualias produk. Uji kualitas bahan kampas rem dilakukan secara bertahap meliputi pengujian serat alam murni, pengujian serat alam murni dengan perlakuan dan pengujian spesimen komposit kampas rem. Pengikat spesimen komposit kampas rem menggunakan phenolic resin, polyester dan akrilic. Dan uji unjuk kerja bahan kampas rem untuk tahap awal lebih ditekankan pada koefisien gesek, kekerasan dan kekuatan tekan.
\end{abstract}

Kata kunci: abu, kapuk randu, koefisien gesek, komposit, perlakuan,rem, serat alam

\section{PENDAHULUAN}

Saat ini pengembanganan serat alam sebagai bahan yang mampu menerima beban gesek (friction material) mulai dikaji dan dianalisa kembali sehubungan efek serbuk bahan rem (brake) dan kopling (clutch) berpengaruh besar terhadap kualitas lingkungan/kesehatan. Aplikasi produk utama perkebunan (karet, kapuk randu, bambu dan rotan) sebagai serat lebih banyak dikembangkan ke produk utama bahan komposit yang cenderung memfokuskan pada sifat/kualitas kekuatan tarik dan kekuatan tekan meliputi produk asesoris mobil, produk rumah tangga, produk mebel, bangunan dan ban.

Produk ban (tire) terbaru dekade terakhir cenderung diproduksi dengan komposisi yang didominasi serat sintetis. Produk samping hasil pertanian/perkebunan yakni kulit mete (chasew) telah diaplikasikan sebagai penguat pada material mampu gesek [1]. Serat alam (yang telah diurai) diberi perlakuan secara kimia meliputi perlakuan permukaan (acetylation) [2], silane [3] dan peroxide [4]. Perlakuan permukaan dilakukan dengan reaksi acetic anhydride untuk memperbaiki kekuatan antar permukaan (interfacial). Perlakuan silane dilakukan untuk meningkatkan kekuatan serat sisi dalam (inner strength) di mana perlakuan diawali dengan perlakuan alkali untuk mengaktifkan gugus $\mathrm{OH}$ dari selulose dan lignin. Selanjutnya perlakuan peroxide dilakukan untuk melapisi serat dengan decumyl peroxide.

Keunggulan bahan asbestos sebagai bahan rem yang murah dan mudah didapat menemui kendala kebijakan internasional. Ada indikasi material asbestos menyebabkan penyakit kanker [5]. Pengunaan bahan penguat untuk meningkatkan kekuatan gesek meliputi lead oxide $(\mathrm{PbO})$ dan oksida logam (metal oxide) [1] menimbulkan polusi udara yang mengganggu saluran pernapasan dan iritasi mata [5]. Penggunaan bahan zinc (Zn) dalam bahan kampas rem juga mulai ditentang oleh lembaga-lembaga pencinta lingkungan. Proses pengeremen dengan mekanisme gesek antara dua permukaan berpotensi menghasilkan serbuk halus dalam waktu yang relatif cepat.

Selain industri otomotif, komposit dengan penguat serat alam banyak di terapkan di industri bangunan, gerabah, kimia \& plastik dan industri lain berbasis bahan baku serat alam. Pangsa pasar otomotif di Indonesia cukup besar di masa sekarang dan akan datang. Dengan Indonesia menjadi pasar otomotif maka pengembangan bahan komposit dari serat alam (termasuk serat dari kapuk randu) untuk komponen pendukung kendaraan akan memberikan manfaat yang besar bagi industri otomotif dan industri agro.

\section{MATERIAL DAN METODOLOGI}

Bahan baku yang digunakan dalam penelitian ini berupa biji kapuk randu (Gambar 1). Penyediaan bahan baku dilakukan dengan mensurvei lokasi penyedia sesuai dengan jumlah yang dibutuhkan. Lokasi penyediaan bahan baku terdapat di beberapa daerah, diantara Kendal, Purwodadi, dan Pati. Bahan baku yang disiapkan sebanyak 2 karung dengan berat $150 \mathrm{~kg}$. Pengeringan biji kapuk dilakukan dengan penjemuran biji kapuk dengan wadah yang telah disiapkan di lingkungan terbuka dengan memanfaatkan sinar matahari. Selain untuk mengeringkan, dalam penjemuran juga dilakukan pembersihan biji kapuk dari pengotor berupa kapas, pasir, dan lain-lain. 
Tabel 1. Komposisi Biji Kapuk Randu.

\begin{tabular}{cc}
\hline Unsur & Persentase \\
\hline Air & $13 \%$ \\
Abu & $6 \%$ \\
Serat kasar & $20 \%$ \\
Lemak & $6 \%$ \\
Protein & $29 \%$ \\
Karbohidrat & $20 \%$ \\
\hline
\end{tabular}

Penggilingan biji kapuk dilakukan dengan mengunakan mesin giling biji. Penggilingan bertujuan agar biji kapuk dibuat menjadi bentuk serbuk, hingga halus. Pembentukan serbuk biji kapuk dilakukan untuk mempermudah proses pengerjaan selanjutnya dalam proses pembuatan abu. Penimbangan serbuk biji kapuk dilakukan untuk mengetahui berat awal dari serbuk biji kapuk serta berat akhir setelah menjadi abu. Penimbangan dilakukan dengan timbangan digital di Laboratorium Metalurgi Fisik Teknik Mesin Universitas Diponegoro.

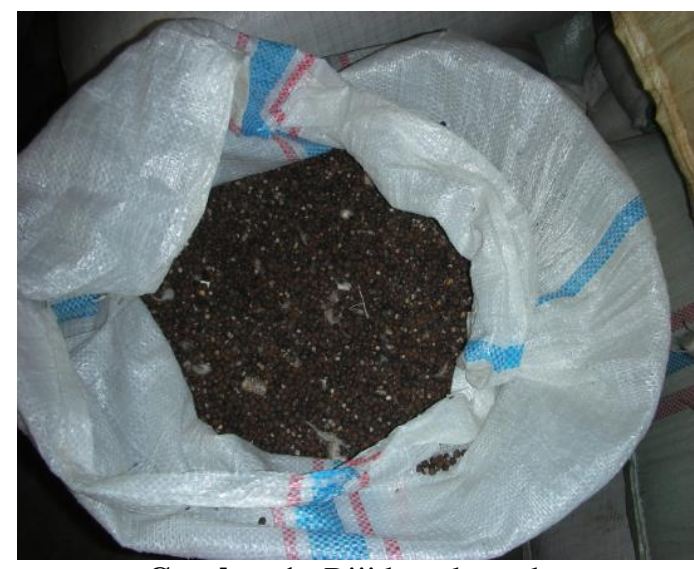

Gambar 1. Biji kapuk randu.

Proses ini dilakukan untuk membuat serbuk biji kapuk menjadi abu dengan cara dipanaskan/dibakar hingga suhu $600^{\circ} \mathrm{C}$ dengan durasi waktu 90 menit [6]. Pembuatan abu menggunakan tungku pemanas (furnace) di Laboratorium Metalurgi Fisik Teknik Mesin Universitas Diponegoro. Pengujian kualitas abu biji kapuk dapat dilihat dari bentuk butir dan distribusi ukuran abu biji kapuk. Pengujian kualitas ukuran abu biji kapuk melakukan sieving menggunakan mesh ukuran 200 (Gambar 2). Tujuan dari sieving untuk mendapatkan material yang halus dan keseragaman ukuran.

Setelah dilakukan penyeragaman ukuran abu, dilakukan pengujian massa jenis dari abu yang akan dibuat menjadi material komposit, untuk mengetahui densitas dari abu yang telah dibuat dari bahan baku biji kapuk. Pengujian dilakukan menggunakan density meter di Laboratorium Metalurgi Fisik Teknik Mesin Universitas Diponegoro didapatkan rata-rata massa jenis dari abu kapuk ialah sebesar $1,03 \mathrm{~g} / \mathrm{cm}^{3}$.

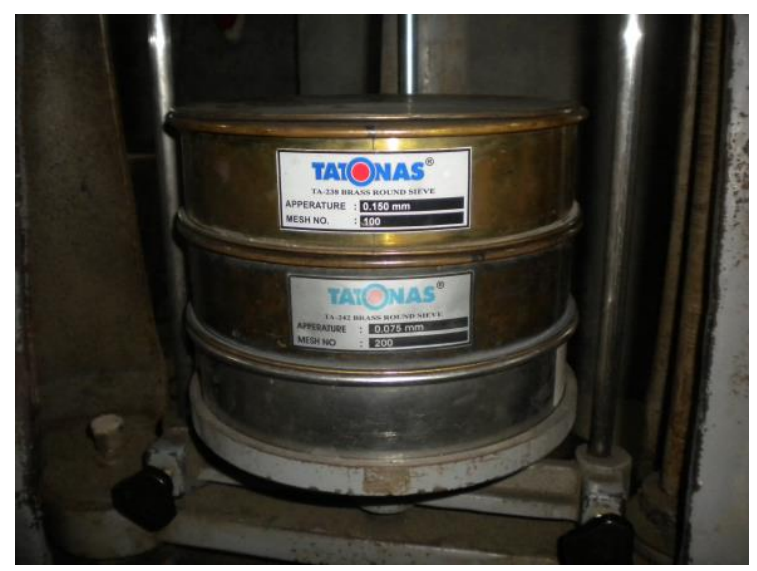

Gambar 2. Mesh ukuran 200. 
Tabel 2. Data Pengujian Massa Jenis Abu Biji Kapuk.

\begin{tabular}{cccc}
\hline No & $\begin{array}{l}\text { Massa } \\
(\text { gram })\end{array}$ & $\begin{array}{c}\text { Volume } \\
\left(\mathrm{cm}^{3}\right)\end{array}$ & Densitas $\left(\mathrm{g} / \mathrm{cm}^{3}\right)$ \\
\hline 1 & 0.16 & 0.15 & 1.04 \\
2 & 0.84 & 0.83 & 1.02 \\
3 & 0.26 & 0.25 & 1.04 \\
\hline
\end{tabular}

Setelah proses pembentukan abu, dilakukan perlakuan kimiawi dengan komposisi pencampuran:

1) Alkali

Massa Abu 100 gram

A1 Komposisi $2 \%$

A2 Komposisi $4 \%$

A3 Komposisi $6 \%$

A4 Komposisi $8 \%$

A5 Komposisi $\quad 10 \%$

Arti 10\%, 100 gram per $1000 \mathrm{ml}$ dikalikan 100\%. Pencampuran abu dengan larutan di dalam bejana gelas, kecepatan pengadukan lambat, pengeringan $50^{\circ} \mathrm{C}$ selama 30 menit.

2) Benzol

Massa Abu 100 gram

B1 komposisi 2,5\%

B2 Komposisi $5 \%$

B3 Komposisi $7,5 \%$

B4 Komposisi $\quad 10 \%$

Arti 10\%, volume benzol per volume campuran alkohol dan air perbandingan 50 : 50 dikalikan 100\%. Pencampuran abu dengan larutan di dalam bejana gelas,kecepatan pengadukan lambat, pengeringan $50^{\circ} \mathrm{C}$ selama 30 menit.

Pembuatan spesimen, dimulai dari pencetakan spesimen hingga proses sintering. Pencetakan dan kompaksi pada abu biji kapuk dilakukan untuk membuat spesimen berbentuk silinder yang solid sehingga bisa dilakukan proses sintering.

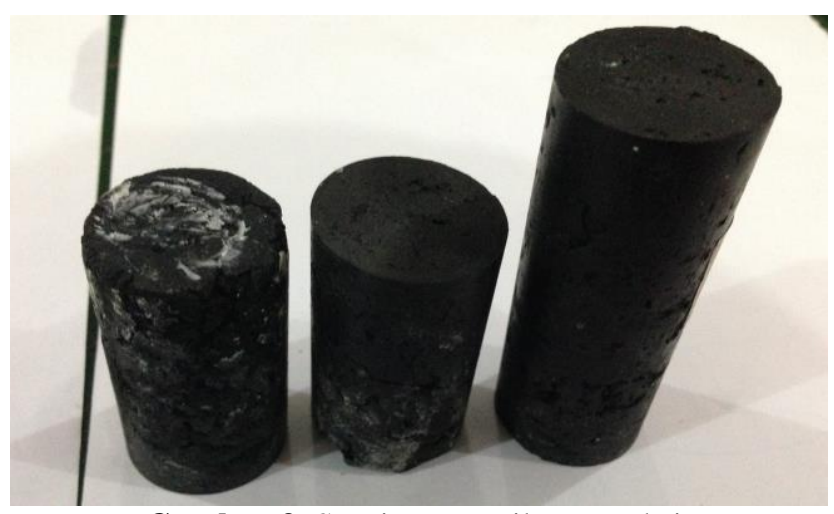

Gambar 3. Spesimen Hasil Kompaksi.

Proses sintering yang dilakukan di Laboratorium Bahan Teknik Mesin Universitas Gadjah Mada. Masingmasing spesimen yang telah dikompaksi (Gambar 3) dimasukkan ke dalam furnace untuk proses sintering pada temperatur $170{ }^{\circ} \mathrm{C}$ untuk spesimen dengan resin polyester dan temperatur $210{ }^{\circ} \mathrm{C}$ untuk spesimen dengan resin epoxy. Diagram proses pemanasan dan pendinginan selama proses sintering dapat dilihat pada Gambar 4 dan Gambar 5.

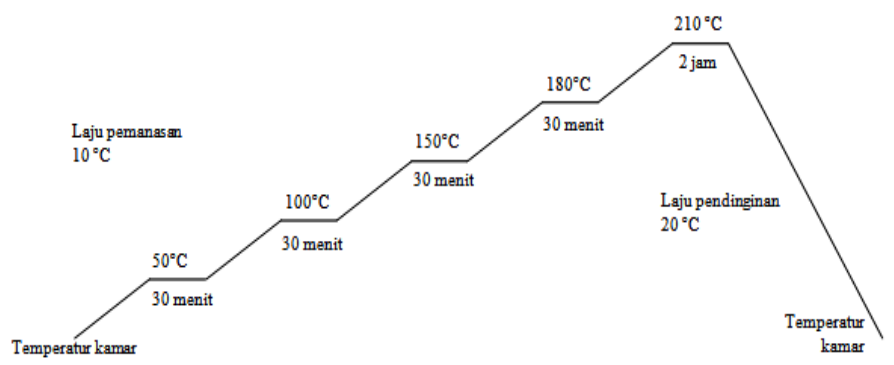

Gambar 4. Skema Pemanasan dan Pendinginan pada Temperatur Sintering Komposit (Epoxy Resin). 


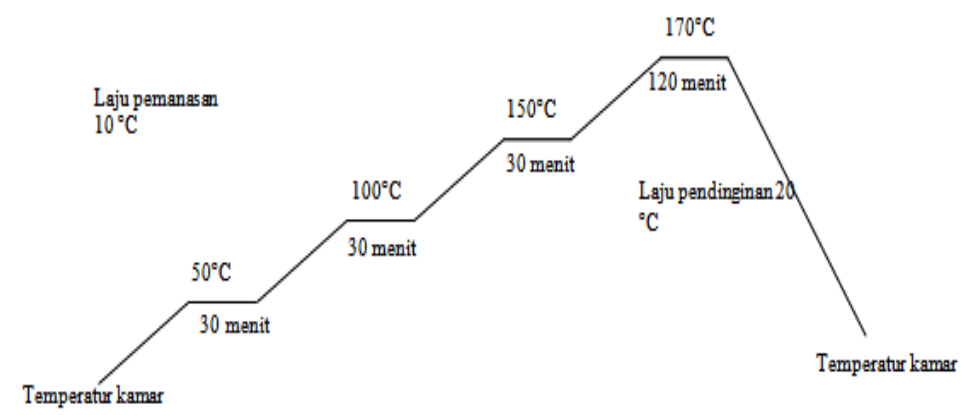

Gambar 5. Skema Pemanasan dan Pendinginan pada Temperatur Sintering Komposit (Polyester Resin).

Pemanasan / pembakaran serbuk biji kapuk dilakukan di Laboratorium Metalurgi Fisik Teknik Mesin Universitas Diponegoro. Serbuk biji kapuk yang telah ditimbang dengan berat 1000 gram dimasukkan ke dalam tungku kemudian dibakar dengan suhu $600^{\circ} \mathrm{C}$ hingga menjadi abu seperti terlihat dalam Gambar 6. Waktu yang diperlukan dalam proses sekali pembakaran serbuk biji kapuk selama 90 menit. Kemudian pembakaran dilakukan berulang serbuk biji kapuk yang telah dibuat hingga semua menjadi abu. Dalam pembuatan abu biji kapuk tersebut akan digunakan selanjutnya untuk pembuatan material komposit.

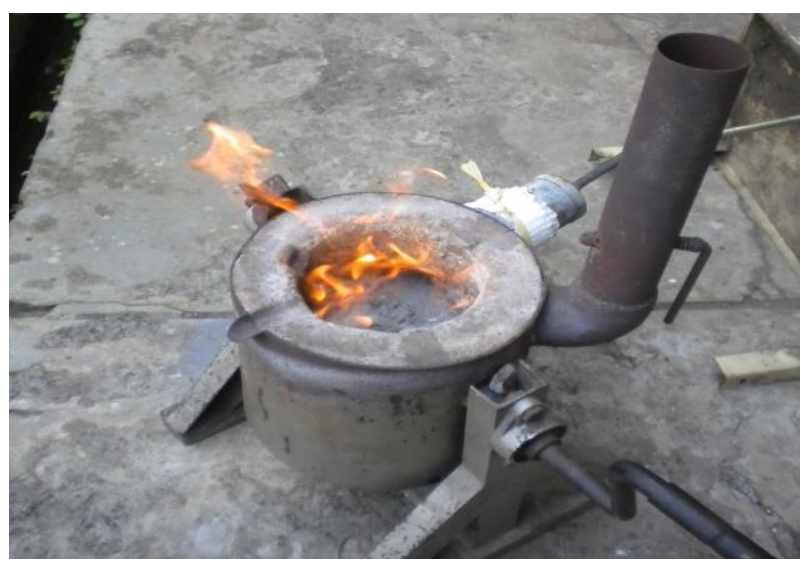

Gambar 6. Pembakaran serbuk biji kapuk.

Pengujian spesimen dilakukan untuk mendapatkan data hasil pengujian. Pengujian spesimen dilakukan dengan beberapa jenis pengujian, diantaranya ada uji tekan (compression test), uji gesek (friction test), keausan dan pengujian kekerasan. Uji kekerasan dilakukan untuk mengetahui salah satu sifat mekanis material komposit yang telah dibuat. Nilai kekerasan dari spesimen tersebut dapat menjadi pembanding dengan nilai kekerasan pada produk kampas rem yang sudah dibuat dipasaran. Pengujian kekerasan dilakukan dengan metode Brinell, Pengujian kekerasan dilakukan menggunakan alat uji N3 emcotest buatan Austria di Laboratorium Metalurgi Fisik Teknik Mesin Universitas Diponegoro.

Keausan umumnya didefinisikan sebagai kehilangan material secara progresif atau pemindahan sejumlah material dari suatu permukaan sebagai suatu hasil pergerakan relatif antara permukaan tersebut dan permukaan lainnya. Pengujian keausan dapat dilakukan dengan berbagai macam metode dan teknik, yang semuanya bertujuan untuk mensimulasikan kondisi keausan aktual. Salah satunya adalah dengan pengujian laju keausan. Pengujian laju keausan dilakukan menggunakan mesin Ogoshi High Speed Universal Wear Testing (Type OAT-U) di Laboratorium Laboratorium Bahan Teknik Mesin Universitas Gadjah Mada.

Kelenturan merupakan sifat mekanik bahan yang menunjukkan derajat deformasi plastis yang terjadi sebelum suatu bahan putus atau patah. Untuk mengetahui kekuatan lentur suatu material dapat dilakukan dengan pengujian lentur terhadap material tersebut. Besar kekuatan lentur tergantung pada jenis material dan pembebanan. Pengujian yang dilakukan three point bending. Pada perhitungan kekuatan lentur ini, digunakan persamaan yang ada pada standar ASTM D790. Pengujian lentur dilakukan menggunakan mesin Hydraulic Ultimate Tensile Machine model WE-1000A di Laboratorium Bahan dan Konstruksi Teknik Sipil Universitas Diponegoro. 


\section{HASIL DAN PEMBAHASAN}

Pengaruh komposisi resin terhadap kelenturan spesimen dilihat melalui Gambar 7 dan 8 grafik dibawah ini.

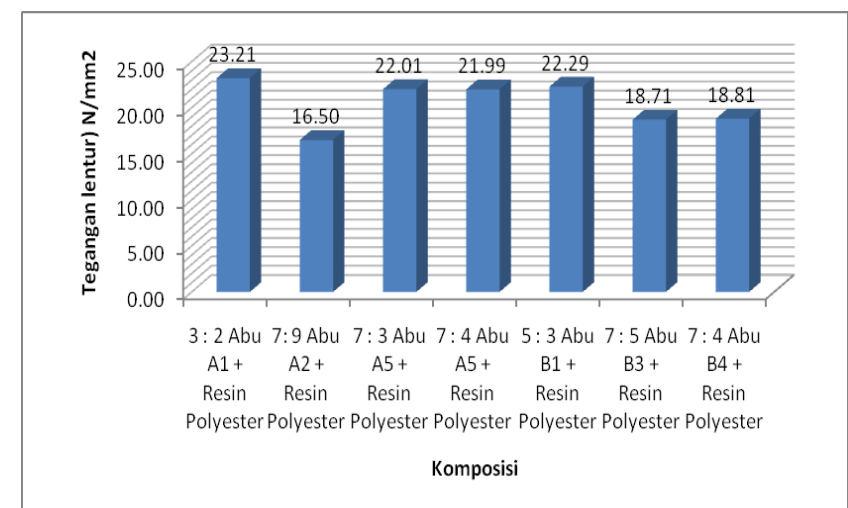

Gambar 7. Grafik Hasil Pengujian Lentur pada Spesimen Resin Polyester.

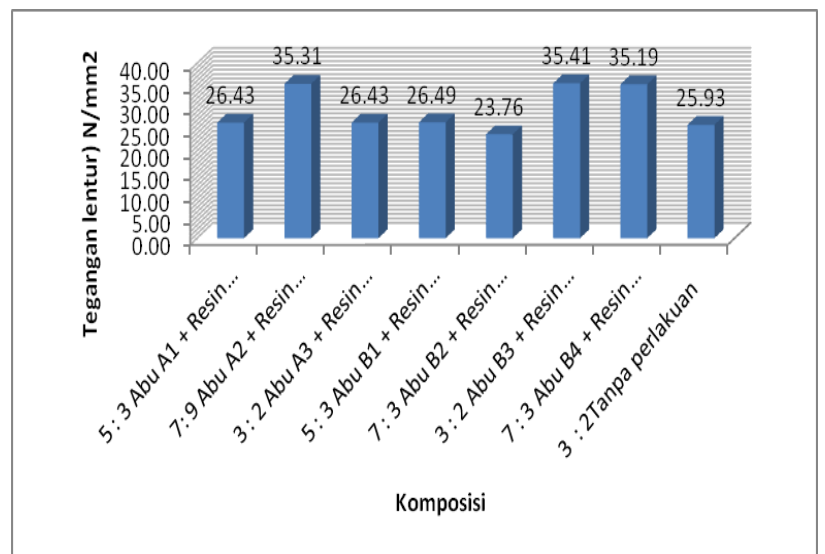

Gambar 8. Grafik Hasil Pengujian Lentur pada Spesimen Resin Epoxy.

Dari gambar grafik tampak jelasa bahwa penambahan resin terjadinya penurunan kelenturan dari spesimen terlihat pada grafik pengujian pada spesimen dengan resin polyester, spesimen yang mempunyai nilai kelenturan yang paling tinggi adalah spesimen dengan komposisi kom. $3: 2$ Abu A1 + Resin Polyester yaitu $23.21 \mathrm{~N} / \mathrm{mm}^{2}$. Sedangkan nilai kelenturan yang paling rendah adalah spesimen dengan komposisi 7: 9 Abu A2 + Resin Polyester yaitu 16.50 $\mathrm{N} / \mathrm{mm}^{2}$. Namun pada spesimen dengan resin epoxy terlihat pada grafik bahwa kelenturan yang didapat lebih lentur dibandingkan spesimen dengan resin polyester. Dan didapat spesimen dengan resin yang paling lentur adalah spesimen dengan komposisi $3: 2$ Abu B3 + Resin Epoxy yaitu $35.41 \mathrm{~N} / \mathrm{mm}^{2}$.

Penambahan resin mengakibatkan pertambahan kekerasan pada spesimen. terlihat pada grafik pengujian pada spesimen dengan resin polyester (Gambar 9), spesimen yang mempunyai nilai kekerasan yang paling tinggi adalah spesimen dengan komposisi 7: 9 Abu A2 + Resin Polyester yaitu 21.66 HBN. Sedangkan nilai kekerasan yang paling rendah adalah spesimen dengan komposisi $7: 4$ Abu A5 + Resin Polyester yaitu 17.5 HBN. Namun pada spesimen dengan resin epoxy terlihat pada grafik bahwa kekerasan yang didapat lebih keras dibandingkan spesimen dengan resin polyester (Gambar 10). Dan didapat spesimen dengan resin yang paling keras adalah spesimen dengan komposisi 7: 9 Abu A2 + Resin Epoxy yaitu 35.78 HBN. 


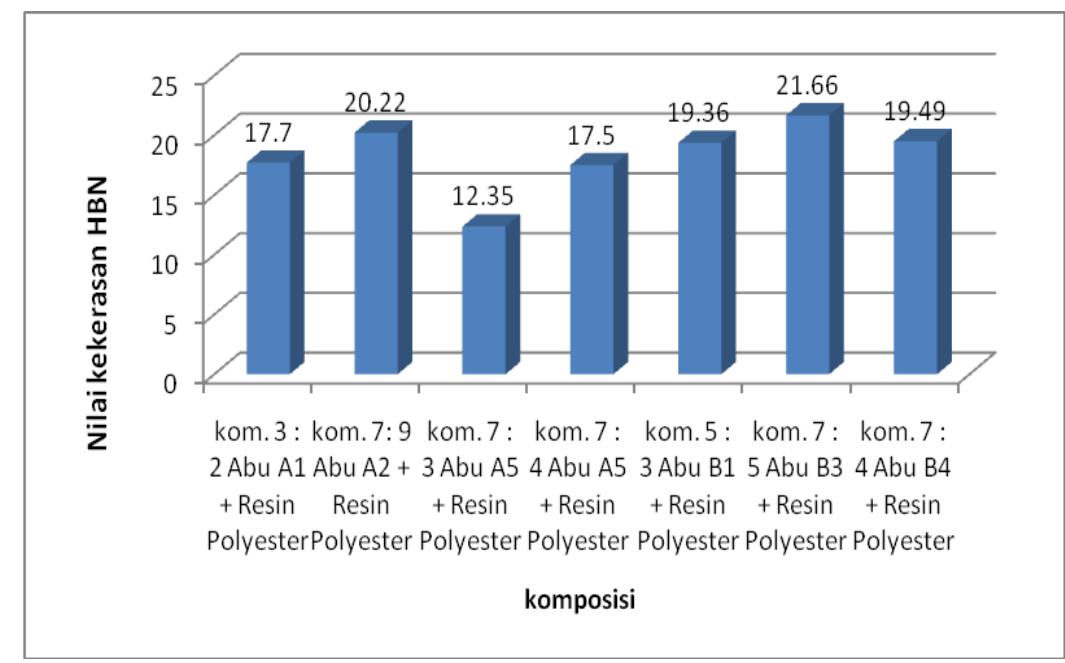

Gambar 9. Grafik Hasil Pengujian Kekerasan pada Spesimen Resin Polyester.

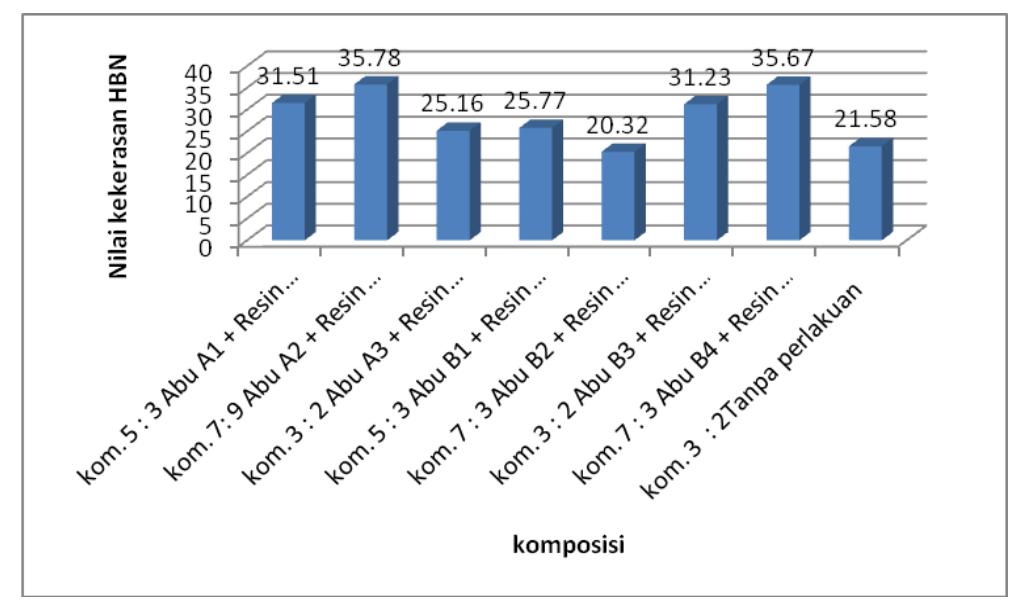

Gambar 10. Grafik Hasil Pengujian Kekerasan pada Spesimen Resin Epoxy.

Dari hasil pengujian tampak jelas bahwa penambahan resin mengakibakan terjadinya penurunan laju keausan dari spesimen terlihat pada grafik pengujian pada spesimen dengan resin polyester, spesimen yang mempunyai laju keausan yang paling tinggi adalah spesimen dengan komposisi kom. $7: 3$ Abu A5 + Resin Polyester yaitu 2,10046E-07 $\mathrm{gram} / \mathrm{mm}^{2}$. Sedangkan laju keausan yang paling rendah adalah spesimen dengan komposisi 7 : 9 Abu A2 + Resin Polyester yaitu $8,12344 \mathrm{E}-08 \mathrm{gram} / \mathrm{mm}^{2}$. Namun pada spesimen dengan resin epoxy terlihat pada grafik bahwa laju keausan spesimen dengan resin yang paling tinggi laju keausannya adalah spesimen dengan komposisi $5: 3$ Abu B1 + Resin Epoxy yaitu 2,87687E-07 gram $/ \mathrm{mm}^{2}$.

Proses sintering dilakukan dengan memanaskan bahan/spesimen hingga mencapai temperatur luluh (melting) atau disekitarnya dan ditahan (didiamkan) sesaat. Tujuan sintering adalah untuk menggabungkan/merekatkan dua partikel atau lebih menjadi material yang padat (masive/compact) sehingga akan diperoleh material dengan sifat teknik yang lebih baik. Perlakuan (treatment) bahan/produk setengah jadi yang berasal dari bahan baku serbuk biasanya dilakukan dengan proses pemadatan (compaction) yang disertai dengan mekanisme sintering [7]. Sehubungan dengan kandungan karbon serat alam pada komposisi bahan kampas rem diatur (setting) relatif dominan terhadap bahan lain maka tolak ukur temperatur sintering mendasarkan pada temperatur luluh (melting) karbon serat serat alam. Ada dua hal yang perlu diperhatikan pada komposit yang diperkuat agar membentuk produk yang efektif yakni komponen penguat harus memiliki modulus elastisitas yang lebih tinggi dari pada komponen matriknya dan harus ada ikatan permukaan yang kuat antara komponen penguat dengan matriks $[8,9,10]$.

\section{KESIMPULAN}

Berdasarkan data dari hasil pengujian dan pembahasan, maka dari penelitian ini dapat disimpulkan:

1) Sifat mekanik bahan kampas rem abu biji kapuk randu yang mempunyai sifat kelenturan yang paling tinggi adalah Abu B3 + Resin Epoxy dengan perbandingan komposisi $3: 2$ yaitu $35.41 \mathrm{~N} / \mathrm{mm}^{2}$. Sedangkan nilai kelenturan yang paling rendah adalah Abu A2 + Resin Polyester dengan perbandingan komposisi 7: 9 yaitu $16.50 \mathrm{~N} / \mathrm{mm}^{2}$.

2) Sifat mekanik bahan kampas rem abu biji kapuk randu yang mempunyai sifat kerasan yang paling tinggi adalah Abu A2 + Resin Epoxy dengan perbandingan komposisi 7: 9 yaitu 35.78 HBN. Sedangkan nilai kekerasan yang paling rendah adalah Abu A2 + Resin Polyester dengan perbandingan komposisi yaitu $16.50 \mathrm{~N} / \mathrm{mm}^{2}$. 
3) Sifat mekanik bahan kampas rem abu biji kapuk randu yang mempunyai laju keausan yang paling tinggi adalah Abu B1 + Resin Epoxy dengan perbandingan komposisi 5 : 3 yaitu 2,87687E-07 gram $/ \mathrm{mm}^{2}$. Sedangkan yang mempunyai laju keausan yang paling rendah adalah Abu A2 + Resin Polyester dengan perbandingan komposisi 7 : 9 yaitu $8,12344 \mathrm{E}-08 \mathrm{gram} / \mathrm{mm}^{2}$.

\section{REFERENSI}

[1] Blau, P.J., 2001, "Composition, Function and Testing of Friction Brake Material and Additives", Metal and Ceramic Division, US Deparment of Energy.

[2] Rowell, R.M., 1998,' Property Enhanced Natural Fiber Composite Materials Based on Chenical Modification', Science Technology of Polymers and Advanced Materials.

[3] Wang, B, Panigrahi, S, Tabil, L., Crerar, W dan Sokansanj, S., 2003,'’Modification Flax Fiber by Chemical Treament ", Presentasi di CSAE/SCGR 2003 Meeting Montreal Quebec.

[4] Joseph, K., Filho, R.D.T., James, B., Thomas, S., dan Carvalho, L.H., 1999, " A Review on Sisal Fiber Reinforced Polymer Composites ', R. Bras. Eng. Agric. Ambiental, Campina Grande, v.3, n.3: 367-379.

[5] Scheneider.A, 2003, "US Imports of Asbestos brake material are on Rise", Sunday Post-Dispatch, vol 125 No. 229: 1

[6] Sumardjono, A., 2007, "Kanvas Rem dari Limbah Pabrik Gula”, Agrinex Indonesia 2007, Kompas 16 Maret 2007: 59.

[7] German, 1994,"Powder Metallurgy Science", second edition, The Pennsylvania State University.

[8] Van Vlack, Lawrence H. Elements of Materials Science and Engineerin. Elements of Materials Science and Engineering. 1989.

[9] Haryadi, G.D., Darmanto, S dan Setyoko, 2008, 'Analisa Ampas Kelapa Sawit sebagai Bahan Kampas Rem', Majalah Gema Teknologi, Periode April, No. 1, Vol 15:9-13.

[10] Haryadi, G.D., Darmanto, S dan Setyoko, 2007, '’Analisa Biji Kapuk Randu sebagai Bahan Kampas Rem', Laporan Penelitian SPI 2007 Undip.

\section{UCAPAN TERIMA KASIH}

Penelitian ini dibiayai oleh Direktorat Penelitian dan Pengabdian kepada Masyarakat Direktorat Jenderal Pendidikan Tinggi (Ditlitabmas Dikti) Kementerian Pendidikan dan Kebudayaan Tahun Anggaran 2013, melalui Daftar Isian Pelaksanaan Anggaran (DIPA) Universitas Diponegoro Nomor DIPA-023.04.2.189815/2013 tanggal 05 Desember 2012. 